\title{
Allele and genotype frequency for milk beta-casein in dairy cattle in the northern region of Tocantins State, Brazil
}

\section{Frequências alélicas e genotípicas para beta-caseína do leite em bovinos leiteiros da microrregião de Araguaína, Tocantins}

\author{
Rodolfo Olinto Rotoli Garcia Oliveira ${ }^{1}$ (D); Minos Esperandio de Carvalho ${ }^{2}$ (i); Matheus Henrique Dias Rodrigues ${ }^{1}$ (D), \\ Mirele Daiana Poleti ${ }^{2}$ (D); José Bento Sterman Ferraz ${ }^{2}$ (D); Ana Beatriz Bezerra Souza ${ }^{1}$ (D), Silvia Minharro ${ }^{1}$ (D); \\ Helcileia Dias Santos ${ }^{1}$ (D); Jorge Luís Ferreira ${ }^{1}$ (D) \\ ${ }^{1}$ Universidade Federal do Tocantins, Escola de Medicina Veterinária e Zootecnia, Campus Araguaína, Araguaína - TO, Brazil \\ ${ }^{2}$ Universidade de São Paulo, Faculdade de Zootecnia e Engenharia de Alimentos, Departamento de Medicina Veterinária, Campus \\ Pirassununga, Pirassununga - SP, Brazil
}

\begin{abstract}
At present, there is a concern about the quality of milk and diseases related to its consumption, as it can generate discomfort and allergic reactions in some individuals due to its protein components. Thus, the present study was developed to identify the allele and genotype frequencies of genes for $\beta$-casein, A1 and A2, in dairy herds in the region of Araguaína-TO, Brazil. Genetic material from 421 animals (crossbred dairy cattle in lactation) was used. All animals were numbered for identification, and DNA samples were extracted from hair bulbs. Samples for two markers from the polymorphic regions were characterized and confirmed by real-time PCR using the ABI Prism 7500 Sequence Detection System (Applied Biosystems). Allele and genotype frequencies were determined using the TaqMan ${ }^{\text {Tu }}$ detection system, where the primer and probe release different fluorescence signals for each allele of the polymorphism. The sampled herd showed frequencies of $28.27 \%$ for the A1 allele and $71.73 \%$ for the A2 allele. Genotype frequencies were 52.96\% (223/421) for A2A2; 37.53\% (158/421) for the A1A2 genotype; and 9.50\% (40/421) for the A1A1 genotype. The frequency of the A1 allele for $\beta$-casein in dairy herds from the northern region of Tocantins was low and is per the results of previous studies. Although the A2A2 genotype of $\beta$-casein had a high relative frequency, the A1A2 genotype is still rather frequent, warranting greater selection pressure.
\end{abstract}

Keywords: Beta-casein. Dairy cattle. Genotyping. Tocantins.

\section{RESUMO}

Atualmente existe uma preocupação em relação à qualidade e doenças que estão relacionadas ao consumo de leite, pois o mesmo pode gerar desconfortos e reações alergicas em alguns indivíduos devido aos seus constituintes protéicos. Assim, o presente estudo teve como objetivo identificar a frequência alélica e genotípica de genes para beta caseína, A1 e A2, em rebanhos leiteiros da região de Araguaína-TO. Foram utilizados material genético de 421 animais (bovinos leiteiros mestiços em lactação), e todos os animais foram numerados para identificação e amostras de DNA foram extraídas de bulbo de folículos pilosos. As amostras para dois marcadores das regiões polimórficas foram caracterizadas e confirmadas por PCR em tempo real, usando um sistema de detecção de sequências ABI Prism 7500 (Applied Biosystems). As frequências alélicas e genotípicas foram determinadas utilizando o sistema de deteç̧ão TaqMan ${ }^{\mathrm{Tm}}$, no qual o primer e a sonda emitem diferentes sinais de fluorescência para cada alelo do polimorfismo. Observou-se frequência do alelo A1 de $28,27 \%$, e do alelo A2 de 71,73\% no rebanho amostral. A frequência genotípica de A2A2 foi de 52,96\% (223/421), com genótipo A1A2 de 37,53\% (158/421), e de 9,50\% (40/421) animais com genótipo A1A1. A frequência do alelo A1 para beta-caseína em rebanhos leiteiros da região norte do Tocantins foi baixa e seguiu a mesma tendência já observada em estudos anteriores. Os genótipos A2A2 da beta-caseína apresentaram frequência relativa alta, entretanto o genótipo A1A2 ainda é bastante frequente, necessitando de maior pressão de seleção.

Palavras-chave: Beta-caseina. Bovino de leite. Genotipagem. Tocantins. 
Correspondence to:

Jorge Luís Ferreira

Universidade Federal do Tocantins, Escola de Medicina

Veterinária e Zootecnia, Campus Araguaína

TO-421, 6

CEP: 77804-970, Araguaína - TO, Brazil

e-mail: jlferreira@uft.edu.br

Received: June 06, 2021

Approved: September 28, 2021

How to cite: Oliveira RORG, Carvalho ME, Rodrigues MHD, Poleti MD, Ferraz JBS, Souza ABB, Minharro S, Santos HD, Ferreira JL. Allele and genotype frequency for milk beta-casein in dairy cattle in the northern region of Tocantins State, Brazil. Braz J Vet Res Anim Sci. 2021;58:e186603. https://doi.org/10.11606/issn.1678-4456. bjvras.2021.186603

\section{Introduction}

Tocantins State is the third-largest milk-producing state in the northern region of Brazil, with 405 million liters of milk produced per year, i.e., $1.20 \%$ of the national bovine milk production (Zoccal, 2020). Although this index is still low, milk holds significant importance for the regional economy, with employment and income-generating potential, especially in family farming.

In milk, $\beta$-casein represents 25 to $35 \%$ of total proteins, bearing two alleles: A1 and A2 (Barbosa et al., 2019). What differentiates these $\beta$-casein variants is the substitution of an amino acid at position 67 of the protein. A1 $\beta$-casein has a histidine residue (His67), whereas A2 $\beta$-casein has a proline (Pro67) (Ramakrishnan et al., 2020).

At present, there is a concern among the population regarding diseases related to the consumption of milk and dairy products (Siqueira, 2019), as it can cause discomfort for some people. According to Ingram et al. (2009), about $65 \%$ of the world population has some degree of allergy or intolerance to milk components. Data referring to food allergy in Brazil are scarce, but it is estimated that 2.2\% of the world population has cow's milk protein allergy (CMPA), which affects 5.4\% of children (Solé et al., 2018; Vieira et al., 2010).

This allergy can be due to any component of milk, the most common being the metabolite produced by the A1A1 genotype of $\beta$-casein. However, this can be corrected through the selection of A2A2 animals and, therefore, genotyping for that genotype may contribute to the nonproduction of this metabolite (Kay et al., 2021).

In some people, to digest milk with $A 1 \beta$-casein, the organism breaks peptide bonds and releases the bioactive peptide $\beta$-casomorphin-7 (BCM-7), which causes allergic reactions. Nonetheless, the presence of the A2 allele prevents peptide bond hydrolysis and inhibits the release of BCM-7 (Kamiński et al., 2007; Sharma et al., 2013).

Compared with conventional milk, A2A2 milk is a product of greater added value that constitutes an option to increase income from milk production. In Brazil, studies related to the frequency of the presence of $\beta$-casein alleles are still scarce, especially in the northern region of the country. Thus, this study was undertaken to examine the allele and genotype frequencies for $\beta$ casein, A1 and A2, in dairy herds in the microregion of Araguaína - TO, Brazil.

\section{Material and Methods}

The present experiment was carried out from August 2020 to February 2021. Three (03) herds were selected from the dairy production chain of the microregion of Araguaína - TO, Brazil, located in the municipalities of Arapoema (Farm 1), Colinas do Tocantins (Farm 2), and Araguaína (Farm 3).

A total of 421 hair bulb samples distributed across three herds, characterized as dairy crossbreeds in production, were collected. The sample number was calculated considering 500,000 lactating cows, a 95\% confidence interval, and a 5\% experimental error, using an electronic calculator ("Calculator. net") with $95 \%$ confidence level ( $\mathrm{Z}=1.96$ standard deviation) and $5 \%$ margin of error. This experiment was approved by the Ethics Committee on Animal Experimentation (CEUA) at the Federal University of Tocantins (approval n. 23.101.002.456/2020-23).

The selection of animals for sampling was based on the following criteria: $60 \%$ of the cows in the first, second, or third lactation, between 30 and 250 days in milk. Breed and age were not considered, due to the composition and genetic diversity of the herds. All properties were characterized as dairy farms. Sires and young service bulls were also sampled.

DNA extraction from the hair follicle was performed at the Animal Breeding Laboratory (LMA) of the Veterinary Medicine Program at the Federal University of Tocantins (UFT), following the protocol described by Olerup \& Zetterquist (1992).

After the extractions of genetic material, the quantity and purity of DNA were determined using a NanoDrop 1000 spectrophotometer (ThermoScientific, Waltham, MA, USA). The genotype samples for two markers from the polymorphic regions were characterized and confirmed by real-time PCR using the ABI Prism 7500 instrument (Applied Biosystems) (Carvalho et al., 2017). 
The allele and genotype frequencies were determined using the TaqMan ${ }^{\text {Tn }}$ detection system, whereby the primer and probe release different fluorescence signals for each allele of the polymorphism and are paired in the target DNA region, allowing the identification of different alleles (A1 and A2) by reading the fluorescence of each sample. When only one fluorescent signal is detected, the sample is homozygous for one allele, and when two different fluorescent signals are detected, the sample is heterozygous, considering both possible alleles (Carvalho et al., 2017).

The probes were synthesized to selectively pair on the DNA template where the polymorphism of interest is located. The rate of heterozygous and homozygous individuals to one of their genotypes was estimated by the fluorescent signals of the probes (Carvalho et al., 2017).

To amplify the genotypes corresponding to the $\mathrm{A} 1$ and A2 alleles for $\beta$-casein, the area of the gene responsible for encoding the protein, a pair of primers previously designed with the regions of interest, containing the respective nucleotide sequences, was used:

Forward - 5' CCCAGACACAGTCTCTAGTCTATCC 3'

Reverse - 5' GGTTTGAGTAAGAGGAGGGATGTTT 3'

And the fluorescence probe, by the following sequences:

Forward - 5' CCCATCC[C]TACAGCCT 3'

Reverse - 5' CCCATCC[A]TACAGCCT 3'

For the real-time polymerase chain reaction (PCR), approximately $15 \mathrm{ng}$ of DNA were used for a reaction volume of $10 \mu \mathrm{L}$, containing $0.25 \mu \mathrm{L}$ Assay Mix (Applied Biosystems), and 5.0 $\mu \mathrm{L}$ of Taqman Master Mix Universal PCR (Applied Biosystems), under reaction conditions of $10 \mathrm{~min}$ at $95^{\circ} \mathrm{C}$ and 45 cycles of $15 \mathrm{~s}$ at $92^{\circ} \mathrm{C}$ and $1 \mathrm{~min}$ at $60^{\circ} \mathrm{C}$ (Carvalho et al., 2017).

By visualizing the genotypes' curve pattern, it was possible to calculate the gene $\left(\mathrm{x}_{\mathrm{i}}\right.$ and $\left.\mathrm{x}_{\mathrm{j}}\right)$ and genotype $\left(\mathrm{x}_{\mathrm{ii}}\right.$, $\mathrm{x}_{\mathrm{ij}}$ and $\mathrm{x}_{\mathrm{ij}}$ ) frequencies, which were determined by directly counting the observed genotypes. To test the observed frequencies, Hardy-Weinberg equilibrium testing was performed (Falconer \& Mackay, 1996).

\section{Results}

The frequencies of the A1 and A2 alleles in the sampled animals were $28.27 \%$ and $71.73 \%$, respectively. Of the total 421 samples, $2.13 \%(09 / 421)$ corresponded to males, sires, of which $0.47 \%$ (02/421) showed the A1A1 genotype; $0.47 \%$ (02/421) A1A2; and 1.19\% (05/421) the A2A2 genotype. Females represented $97.86 \%$ (412/421) of the analyzed herd, with $9.02 \%$ (38/421) having the A1A1 genotype; 37.05\% (156/421) A1A2; and 51.79\% (218/421) the A2A2 genotype.
At farm I, 67 animals were genotyped. Of these, 17.91\% (12/67) showed the A1A1 genotype; 29.85\% (20/67); $\mathrm{A} 1 \mathrm{~A} 2$ and $52.24 \%(35 / 67)$ the A2A2 genotype. At farm II, 149 animals were genotyped, consisting of $6.04 \%$ (9/149) with the A1A1 genotype; 40.94\% (61/149) with A1A2; and $53.02 \%$ (79/149) with A2A2. Finally, oat farm III, 205 animals were genotyped, with 9.27\% (19/205) showing the A1A1 genotype; $37.56 \%$ (77/205) A1A2; and 53.17\% (109/205) A2A2 (Figure 1).

All properties were characterized as dairy farms, with average milk production of $15.8 \mathrm{~L} /$ animal and an average fat content of $4.11 \%$. The herds exhibited a great variation in their breed composition, with $41.33 \%$ of the animals characterized as crossbred (Bos taurus $\times$ Bos indicus), $49.88 \%$ as Girolando breed, $7.60 \%$ as Gir breed, and the remaining $1.19 \%$ as other breeds (Jersey and Sindhi). A noteworthy trait of the crossbred animals is that, in phenotypic terms, the zebu genetic composition prevailed over other European phenotypes, although the contribution of each breed could not be defined.

This phenotypic characterization possibly explains the higher frequency of the A2A2 genotype, which represented $20.66 \%(87 / 421)$ of the total herd and $50 \%(87 / 174)$ of the group of animals from crossbreeding. Among the other crossbred animals, 9.77\% (17/174) showed the A1A1 genotype and $40.23 \%$ (70/174) A1A2.

In all herds analyzed, the frequency of A2 alleles was higher than that of A1, with A2A2 genotype seen in $52.97 \%$ of the evaluated animals, A1A2 in $37.53 \%$, and $\mathrm{A} 1 \mathrm{~A} 1$ in $9.50 \%$. Figure 1 represents the absolute and relative frequencies of the genotypes for milk $\beta$-casein in each of the analyzed herds.

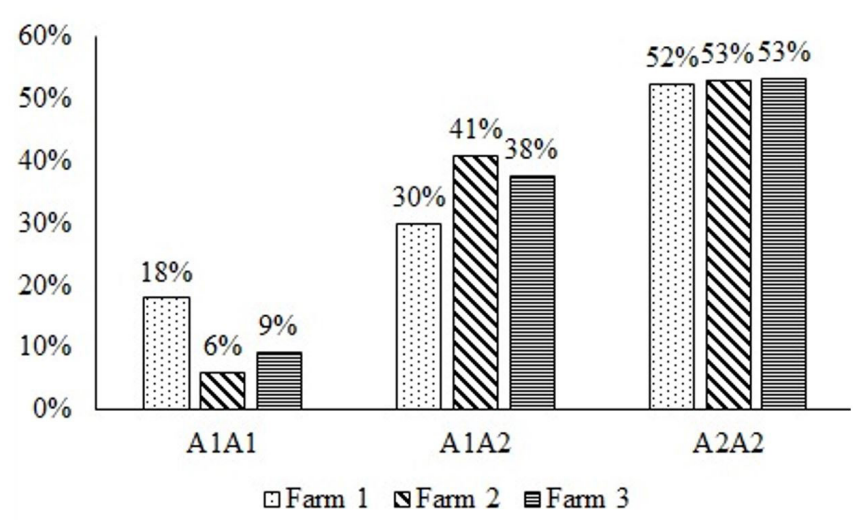

Figure 1 - Absolute and relative frequencies of genotypes for milk beta-casein (A1A1, A1 A2, and A2A2) in hair bulb samples collected in three dairy cattle herds in the northern region of Tocantins State, Brazil, 2020-2021. 


\section{Discussion}

This herd characterization somehow explains the nonobservance of Wardy-Weinberg equilibrium in the studied population, since the variability is large and selection is present in the herds. Another characteristic that corroborates this statement is the high frequency of the A2A2 genotype (55.55\%) in the service bulls of the farm (05/09). Yet another aspect that may have contributed is the use of $100 \%$ semen from bulls already genotyped for A2A2 on the females.

The presented results do not differ from those reported in the previous studies in Brazil (Lima et al., 2014; Paschoal et al., 2017; Vercesi, 2011), which overall indicate a higher frequency of the $\mathrm{A} 2$ allele and its $\mathrm{A} 2 \mathrm{~A} 2$ genotype over the $\mathrm{A} 1$ allele and the $\mathrm{A} 1 \mathrm{~A} 1$ genotype. Thus, it suggests that many breeders have already been directing mating to increase the frequency of A2A2 genotypes.

Lima et al. (2014) and Vercesi (2011) evaluated Gir cows and observed a higher frequency of the A2A2 genotype, which represented 0.85 for the first author and 0.96 for the second. The frequency of the A1 allele can vary across breeds, with some of them having a lesser predisposition for this allele and thus the A2 allele predominating. In this way, the high zebu composition of the herd may have contributed to this frequency, since zebu breeds have a higher frequency of the A2 allele (Paschoal et al., 2017).

In Brazil, studies investigating the frequency of the presence of alleles for $\beta$-casein are still rare, especially in Zebu herds. In a study with dairy Gir cows, Paschoal et al. (2017) found that $41 \%(7 / 17)$ had the A1A2 allele and 59\% (10/17) the A2A2 allele.

It is known that all mammalian species once produced A2 $\beta$-casein only, but because of a genetic mutation that occurred approximately 10,000 years ago, some cows started to produce A $1 \beta$-casein. And, due to a selection process, this gene (A1) is found more frequently in European breeds. Kaminski et al. (2007) found a higher frequency of the A1 allele in taurine breeds. Hanusová et al. (2010) identified, in the Holstein breed, a higher frequency for the A1 allele, of $54 \%$ and $60 \%$ among females and males, respectively.

In the dairy breed Gir, in turn, frequencies of $89 \%$ for the A2 allele and $11 \%$ for the A1 allele were reported (Vercesi, 2011). Therefore, there is an association between genetic polymorphism and the breed, with zebu breeds having a higher frequency of the A2 allele. Because most of the sampled animals were characterized as zebu and/or crossbred, this condition may explain the observed frequency.

In a study carried out in the state of Rio Grande do Norte, Rangel et al. (2017) found frequencies of 98 and $97 \%$ for the A2 allele and $96 \%$ and $93 \%$ for the A2A2 genotype in the Gir and Guzerat breeds, respectively. According to Kamiński et al. (2007), the frequency of the A1 allele in different breeds ranges from 6\% (Guernsey), 1 to $12 \%$ (Jersey), and 31 to 66\% (Holstein). Tailford et al. (2003) stated that the A2 allele is predominant in zebu breeds.

The observed results regarding the frequency of the A2 allele compared with the low frequency of the A1 $\beta$-casein allele indicate that these herds have low production of BCM7. Thus, the selection of animals for the $\mathrm{A} 2 \mathrm{~A} 2$ genotype is less likely to cause the same health problems as milk with a high amount of A1 $\beta$-casein (Pereira, 2018). Studies led by Jianqin et al. (2016) showed that individuals who consumed A1 milk tend to experience significantly greater symptoms of digestive discomfort, delayed gastrointestinal transit, and gastroenteritis and that it may trigger lactose intolerance when compared with A2 milk.

Beta-casomorphin-7, a metabolite of A1 $\beta$-casein, also increases predisposition to other diseases such as human ischemic heart disease (McLachlan, 2001), type-1 diabetes mellitus (Elliott et al., 1999), arteriosclerosis (Tailford et al., 2003), and autism (Sokolov et al., 2014).

Therefore, the genotyping of animals for this gene can contribute to reducing the incidence of these diseases as a result of the ingestion of milk and its derivatives. Additionally, studies suggest that cows genotyped as A2A2 produce milk with higher protein content. In contrast, results regarding fat content are controversial (Nilsen et al., 2009; Olenski et al., 2010; Paschoal et al., 2017). Such characteristics of A2A2 milk culminate in a product with greater added value compared with conventional milk, constituting an option to increase income from milk production.

Milk holds great economic importance to the State of Tocantins, with employment and income-generating potential. Currently, some farms have significantly invested in improving their herds and sought to invest in the sale of differentiated products. However, there is still a need for technical monitoring, with guidelines to promote an efficient selection and formation of a differentiated market.

\section{Conclusion}

The frequency of the A1 allele for $\beta$-casein in dairy herds in the northern region of Tocantins was low and is per the results of previous studies. The A2A2 genotypes of $\beta$-casein had a high relative frequency; however, the A1A2 genotype is still rather frequent, warranting greater selection pressure, since it is recommended to cull animals with this genotype.

\section{Conflict of interests}

All authors declare that there are no conflicts of interest. 


\section{Ethics Statement}

The project entitled 'Frequencies of A1 and A2 betacasein alleles in dairy cattle herds from the mesoregion of Araguaína - Tocantins', case n. 23101.002456/2020-23, under the responsibility of Jorge Luís Ferreira, complies with the ethical standards established by the procedural law for the scientific use of animals, of October 8th, 2008, and its execution was approved by the Ethics Committee on Animal Use at the Federal University of Tocantins. Araguaina, 06/10/2020.

\section{References}

Barbosa MG, Souza AB, Tavares GM, Antunes AEC. Leites A1 e A2: revisão sobre seus potenciais efeitos no trato digestório. Segur Aliment Nutr. 2019;26:1-11. http://dx.doi. org/10.20396/san.v26i0.8652981.

Carvalho ME, Eler JP, Bonin MN, Rezende FM, Biase FH, Meirelles FV, Regitano LCA, Coutinho LL, Balieiro JCC, Ferraz JBS. Genotypic and allelic frequencies of gene polymorphisms associated with meat tenderness in Nellore beef cattle. Genet Mol Res. 2017;16(1). http://dx.doi. org/10.4238/gmr16018957. PMid:28218779.

Elliott RB, Harris DP, Hill JP, Bibby NJ, Wasmuth HE. Type I (insulin-dependent) diabetes mellitus and cow milk: casein variant consumption. Diabetologia. 1999;42(3):292-6. http://dx.doi.org/10.1007/s001250051153. PMid:10096780.

Falconer DS, Mackay TFC. Introduction to quantitative genetics. 4th ed. Edinburgh, Scotland: Longman Group Limited; 1996.

Hanusová E, Huba J, Oravcová M, Polák P, Vrtková I. Genetic variants of beta-casein in Holstein dairy cattle in Slovakia. Slovak J Anim Sci. [Internet]. 2010 [cited 2021 June 6];3(2):63-6. Available from: http://www.cvzv.sk/ slju/10_2/Hanusova.pdf.

Ingram CJE, Mulcare CA, Itan Y, Thomas MG, Swallow DM. Lactose digestion and the evolutionary genetics of lactase persistence. Hum Genet. 2009;124(6):579-91. http:// dx.doi.org/10.1007/s00439-008-0593-6. PMid:19034520.

Jianqin S, Leiming X, Lu X, Yelland GW, Ni J, Clarke AJ. Effects of milk containing only A2 beta casein versus milk containing both $\mathrm{A} 1$ and $\mathrm{A} 2$ beta casein proteins on gastrointestinal physiology, symptoms of discomfort, and cognitive behavior of people with self-reported intolerance

\section{Acknowledgements}

This study was carried out with support from the National Program for Academic Cooperation in the Amazon - PROCAD/Amazonia, by the Coordination for the Improvement of Higher Education Personnel - CAPES/Brazil (Process n. 88881.200559/2018-01, Support n. 1696/2018 and Process n. 88887.200558/2018-00). Thanks are also extended to the Breeding Research and Extension Center in Animal Genetics (NAPGEM) at the Federal University of Tocantins, Araguaína Campus.

to traditional cows' milk. Nutr J. 2016;15:35. http://dx.doi. org/10.1186/s12937-016-0147-z. PMid:27039383.

Kamiński S, Cieslinska A, Kostyra E. Polymorphism of bovine betacasein and its potential effect on human health. J Appl Genet. 2007;48(3):189-98. http://dx.doi.org/10.1007/ BF03195213. PMid:17666771.

Kay SS, Delgado S, Mittal J, Eshraghi RS, Mittal R, Eshraghi AA. Beneficial effects of milk having A2 $\beta$-casein protein: myth or reality? J Nutr. 2021;151(5):1061-72. http://dx.doi. org/10.1093/jn/nxaa454. PMid:33693747.

Lima TCC, Rangel AHN, Medeiros LGZ, Coutinho LL, Peixoto MGCD, Borba LH, Lima GFC. Sem contraindicação: estudo confirma capacidade do zebu de produzir leite não alergênico. Revista ABCZ. 2014;84:87-9.

Mclachlan CN. Beta casein A1, ischemic heart disease mortality and other illness. Med Hypotheses. 2001;56(2):262-72. http://dx.doi.org/10.1054/mehy.2000.1265. PMid:11425301.

Nilsen H, Olsen HG, Hayes B, Sehested E, Svendsen M, Nome T, Meuwissen T, Lien S. Casein haplotypes and their associations with milk production traits in Norwegian Red cattle. Genet Sel Evol. 2009;41(1):24. http://dx.doi. org/10.1186/1297-9686-41-24. PMid:19284706.

Olenski K, Kaminski S, Szyda J, Cieslinska A. Plymorphism of the beta-casein gene and its association with breeding value for production traits of Holstein-Frisian bulls. Livest Sci. 2010;131(1):137-40. http://dx.doi.org/10.1016/j. livsci.2010.02.023.

Olerup O, Zetterquist H. HLA-DR typing by PCR amplification with sequence-specific primers (PCR-SSP) in 
2 hours: an alternative to serological DR typing in clinical practice including donor-recipient matching in cadaveric transplantation. Tissue Antigens. 1992;39(5):225-35. http://dx.doi.org/10.1111/j.1399-0039.1992.tb01940.x. PMid:1357775.

Paschoal JJ, Silva MB, Hortolani B. Beta caseina A2e sua relação com a produção e composição do leite de vacas Gir leiteiro [Internet]. In: 27 Congresso Brasileiro de Zootecnia: ZOOTEC 2017; Santos. Campinas: Galoá; 2017 [cited 2021 June 6]. Available from: https://proceedings.science/zootec/ papers/beta-caseina-a2-e-sua-relacao-com-a-producao-ecomposicao-do-leite-de-vacas-gir-leiteiro.

Pereira TC. Identificação dos alelos A1 e A2 para o gene da beta-caseína na raça Crioula Lageana [final paper]. Florianópolis: Centro de Ciências Agrárias, Universidade Federal de Santa Catarina; 2018.

Ramakrishnan M, Eaton TK, Sermet OM, Savaiano DA. Milk containing A2 $\beta$-casein only, as a single meal, causes fewer symptoms of lactose intolerance than milk containing $A 1$ and $A 2 \beta$-caseins in subjects with lactose maldigestion and intolerance: a randomized, double-blind, crossover trial. Nutrients. 2020;12(12):3855-69. http://dx.doi.org/10.3390/ nu12123855. PMid:33348621.

Rangel AHN, Zaros LG, Lima TC, Borba LHF, Novaes LP, Mota LFM, Silva MS. Polymorphism in the Beta Casein Gene and analysis of milk characteristics in Gir and Guzerà dairy cattle. Genet Mol Res. 2017;16(2):1-9. http://dx.doi. org/10.4238/gmr16029592. PMid:28549202.

Sharma V, Narotam S, Prem RS, Binish J, Satish CN, Singh RK. Amplification of the bovine beta casein generelevance to modern human health. Am J PharmTech Res [Internet]. 2013 [cited 2021 June 6];3(1):439-44. Available from: https:// www.academia.edu/17193808/Amplification_of_the_Bovine_ Beta_Casein_Gene_Relevance_to_Modern_Human_Health.

Siqueira KB. Leite e derivados: novas tendências. In: Empresa Brasileira de Pesquisa Agropecuária - EMBRAPA. Anuário Leite 2019. Sua excelência, o consumidor. Novos produtos e novas estratégias da cadeia do leite para ganhar competitividade e conquistar os clientes finais. São Paulo: Texto Comunicação Corporativa; 2019 [cited 2021 June 6]. p. 74-5. Available from: https://ainfo.cnptia.embrapa.br/ digital/bitstream/item/198698/1/Anuario-LEITE-2019.pdf.

Sokolov O, Kost N, Andreeva O, Korneeva E, Meshavkin V, Tarakanova Y, Dadayan A, Zolotarev Y, Grachev S,
Mikheeva I, Varlamov O, Zozulya A. Autistic children display elevated urine levels of bovine casomorphin-7 immunoreactivity. Peptides. 2014;56:68-71. http://dx.doi. org/10.1016/j.peptides.2014.03.007. PMid:24657283.

Solé D, Silva LR, Cocco RR, Ferreira CT, Sarni RO, Oliveira LC, Pastorino AC, Weffort V, Morais MB, Barreto BP, Oliveira JC, Castro APM, Franco JM, Neto HJC, Rosário NA, Alonso MLO, Sarinho EC, Yang A, Maranhão H, Toporosvski MS, Epifanio M, Wandalsen NF, Rubini NM. Consenso Brasileiro sobre Alergia Alimentar: 2018 - Parte 1 - Etiopatogenia, clínica e diagnóstico. Documento conjunto elaborado pela Sociedade Brasileira de Pediatria e Associação Brasileira de Alergia e Imunologia. Arq Asma Alerg Imunol. 2018;2(1):738. http://dx.doi.org/10.5935/2526-5393.20180004.

Tailford KA, Berry CL, Thomas AC, Campbell JH. A casein variant in cow's milk is atherogenic. Atherosclerosis. 2003;170(1):13-9. http://dx.doi.org/10.1016/S00219150(03)00131-X. PMid:12957678.

Vercesi Filho AE. Identificação de alelos para o gene da beta-caseína na raça gir leiteiro. Pesqui Tecnol [Internet]. 2011 [cited 2021 June 6];8(2):1-5. Available from: http:// aptaregional.sp.gov.br/acesse-os-artigos-pesquisa-e-tecnologia/ edicao-2011/2011-julho-dezembro/1249-identificacao-dealelos-para-o-gene-da-beta-caseina-na-raca-gir-leiteiro-1/ file.html.

Vieira MC, Morais MB, Spolidoro JV, Toporovski MS, Cardoso AL, Araujo GT, Nudelman V, Fonseca MC. A survey on clinical presentation and nutritional status of infants with suspected cow' milk allergy. BMC Pediatr. 2010;10:25. http://dx.doi.org/10.1186/1471-2431-10-25. PMid:20416046.

Zoccal R. Estados e regiões: destaques em produção. In: Empresa Brasileira de Pesquisa Agropecuária - EMBRAPA. Anuário Leite 2020. Leite de vacas felizes [Internet]. São Paulo: Texto Comunicação Corporativa; 2020 [cited 2021 June 6]. p. 38-9. Available from: https://www.embrapa.br/ busca-de-publicacoes/-/publicacao/1124722/anuario-leite2020-leite-de-vacas-felizes.

Financial Support: Financial support National Program for Academic Cooperation in the Amazon - PROCAD/ Amazônia, by the Coordination for the Improvement of Higher Education Personnel - CAPES/Brazil (Process n. 88881.200559/2018-01, support n. 1696/2018). 